\title{
Krytyka filozoficzna w Europie i na świecie wobec globalizacji i terroryzmu*
}

\author{
Jacques POULAIN**
}

\section{KEYWORDS}

transcultural dialogue; judgement of truth; theory of communicative action; globalization; crisis of humanity

\section{ACKNOWLEDGEMENT / ŹRÓDEO PRZEKŁADU}

Poulain, J. (2011). La critique philosophique en Europe et dans le monde face à la mondialisation et aux terrorismes. Cabiers critiques de philosophie, 11, 195-206.

* Wystąpienie zaprezentowane podczas Dnia Filozofii UNESCO w Palermo (Sycylia) 18 listopada 2008 roku.

** Emerytowany profesor katedry UNESCO w dziedzinie filozofii kultury i instytucji (o charakterze europejskim) na Uniwersytecie Paris VIII. 
Globalizacja ekonomiczna, wojny kultur i terroryzmy wszelkiej maści to oblicza dzisiejszego kryzysu człowieczeństwa. Fenomeny te skłaniają filozofię ze wszystkich kontynentów do zastanowienia się nad związkiem, prawdziwym lub domniemanym, jaki łączy ją z tymi rozmaitymi formami irracjonalności. Skonfrontowana z samą sobą, odkąd Husserl postawit ją naprzeciw „kryzysu europejskiego człowieczeństwa”, filozofia musi uznać fałszywość obrazu człowieka, który generuje te kryzysy, a który sama stworzyła: człowieka, który jako duch jest wrogi samemu sobie jako pożądaniu i ciału i który, takim będąc, musi zapewnić sobie panowanie nad sobą i światem.

\section{KRYTYKA FILOZOFICZNA W EUROPIE W OBLICZU GLOBALIACJI}

Globalizacja zachodzi dziś jako proces systematycznego zalewania państw prawa międzynarodowymi rynkami finansowymi i korporacjami. Pozytywne efekty fuzji tych ostatnich ukazują się pod postacią wyrafinowania adaptacji oferty do popytu, jakim jest poddanie asortymentu, produktów i stosunków produkcji dyktatom konsensualnego zapotrzebowania. Adaptacja ta dumnie prezentuje swoją niezależność względem państw prawa i partii politycznych oraz kwestionuje bez skrupułów ich imperatywy oraz sztywne i arbitralne zakazy. Aby się usprawiedliwić, przywołuje obiektywność zależną od efektywnego i skutecznego usatysfakcjonowania maksymalnej ilości pragnień oraz poszanowanie autarkicznej niezależności ludzi i nacji, przedstawiając wszelkie uregulowania społeczne jako logiczną konsekwencję postępu homogenizacji światowego rynku oraz ukazując je jako tak samo obiektywne jak sam postęp naukowy czy techniczny. Człowieczeństwo jednostek i grup zostaje zredukowane do łączenia owego dążenia do maksymalnych gratyfikacji konsumacyjnych z korzystaniem z negatywnej wolności przez wszystkich i wobec wszystkich. Globalizacja daje światowemu rynkowi i kosmopolitycznemu konsensusowi rolę niepodważalnej instancji, nadanej przez pierwotne religie sacrum, mimo iż deregulacje rynku wskutek spekulacji banków radośnie ją zakłamują.

Ponieważ, począwszy od Sokratesa starającego się realizować maksymę „Poznaj samego siebie”, krytyka filozoficzna jest powiązana z krytyką wszelkiego konsensusu, często była mylona z niebezpieczeństwem, jakie przedstawia: kwestionowaniem podłoża konsensualnego, na którym się opiera. Będąc terrorystą duchowym poprzez kwestionowanie konsensualnych ugód, filozof wydawał się bezpośrednio odpowiedzialny za praktyczne wdrażanie idei oświecenia podczas rewolucji francuskiej i ówczesnego terroru praktykowanego na obywatelach w celu zmuszenia ich do bycia wolnymi. Wszystko dzieje się tak, jakby dziś jeszcze krytyka filozoficzna była odpowiedzialna za niemal jednogłośne „nie” wypowiedziane przez międzynarodową opinię publiczną wobec 
fenomenów deregulacyjnych, spowodowanych globalizacją ekonomiczną. Demokracja liberalna Stanów Zjednoczonych rozpowszechniła tę globalizację poprzez zgeneralizowane eksperymentowanie na świecie i na człowieku oraz poprzez wykorzystywanie konsensusu, czemu się oddała, by uniknąć osądzenia wygenerowanej przez siebie kapitalistycznej niesprawiedliwości. Sprowokowało to w rezultacie ogólnoświatową przemoc terrorystyczną - tak samo ślepą i eksperymentalną. Krytyka filozoficzna w Europie zdecydowanie odseparowała się oczywiście od tej opresyjnej riposty jeszcze przed jej pojawieniem się, jednak musi stawić czoła wojnie kultur stanowiącej podłoże terroryzmu. Każda kultura jawi się bowiem wobec globalizacji jako jedyny horyzont, w którym jednostki i grupy zdają się znajdywać swoją prawdę; jednak wszelka kultura, tak jak i sama globalizacja, rości sobie wyłączność do prawdy, wypowiadając tym samym wojnę pozostałym. Radykalne wykluczenie osób biednych i z marginesu, jakie spowodował liberalizm, doprowadziło Jürgena Habermasa do zaatakowania źródła zła i próby wyleczenia zaawansowanych demokracji liberalnych poprzez przywrócenie wśród opinii publicznej świadomości etycznej, dążącej do realizowania ideału sprawiedliwości, oraz poprzez odwołanie się do republikańskich procedur legislacyjnych w celu ustalenia warunków tego, co nazywa on demokracją deliberatywną, zainspirowaną współczesnym ideałem państwa prawa.

Ani światowe propagowanie neoliberalizmu, ani etyka republiki europejskiej nie są jednak w stanie rozstrzygnąć losów tego totalnego eksperymentowania na człowieku i świecie. Aby to dostrzec, trzeba umieć zgłębić ograniczenia nieodłączne dynamice systemów prawnych, moralnych i politycznych, przejętych od europejskiej nowożytności. Podczas gdy odziedziczona nowoczesna teoria prawa czerpie prawa człowieka z równości pomiędzy ludźmi i z wolności działania, którą posiadają oni jako byty racjonalne, współczesna filozofia twierdzi, że człowiek jest bytem językowym, gdyż potrzebuje on formułować sądy, których prawdziwość musi zostać zaakceptowana przez jego partnerów społecznych, aby mógł zostać uznanym za człowieka przez swoich towarzyszy. Równość innym i wolność działania nie mogą być już uznawane tylko i wyłącznie za wrodzoną własność (propriété innée), posiadaną a priori przez każdego, którą należałoby chronić tak, jak chroni się swoje prawa do zdobywania rzeczy materialnych, tj. poprzez tworzenie kontraktów ewidencjonujących kontrolę właścicieli nad ich mieniem i zabraniających innym przywłaszczenia sobie tegoż. Jako słuchacz i odbiorca drugiego człowieka i samego siebie każdy jest przysposobiony do oceny obiektywności swoich warunków życia oraz do działania zależnie od prawdziwości sądów, którymi potrafi się dzielić. Dokonywana przez człowieka ocena prawdziwości sądów opiera się więc jedynie na owym działaniu i dzieleniu się. Dotyczy to zarówno jego wiedzy i prawości działań, jak i obiektywności jego pragnień, które każdy musi rozpoznać jako ludzkie. Nie wystarczy już również samo przyznanie każdemu, za pomocą kontraktu demokratycznego, 
wolności prowadzenia się, respektującej uzyskane dzięki tym sądom wyniki; należy także móc zorganizować każdemu możliwość uznania, przez siebie i przez innych, prawdziwości sądów - zuniwersalizować prawdziwą filozoficzną kulturę sądzenia, będącą fundamentem demokracji kosmopolitycznej.

Aby móc to zrobić, należy zwrócić każdemu możliwość wydawania sądu oraz uznania niesprawiedliwości społecznej, która rozprzestrzenia się pod postacią prywatyzacji świata, nazywanej globalizacją. Albowiem niesprawiedliwość społeczna charakteryzująca dziś liberalne eksperymentowanie sprawiedliwością na całym świecie oraz psychiczna dekonstrukcja psyche, która z tego eksperymentowania pochodzi, są owocem choroby refleksji i filozoficznego błędu - wiary w konieczność obowiązku wyleczenia w człowieku, stworzonym jako istota duchowa, jego domniemanego wroga jawiącego się mu pod postacią istoty pożądającej.

Specyfika choroby kapitalistycznej ma źródło w perwersji liberalnej świadomości moralnej, która jest jej nosicielem i ją rozprzestrzenia. Jak zdiagnozował Max Weber, pogoń kapitalistów za zbawienną autocertyfikacją w tworzeniu warunków życia i pracy pracowników skłania tych pierwszych do ponownej inwestycji zysków w przedsiębiorstwo, zmuszając do pozbawiania pracowników udziału w nich. Dzieje się tak jedynie dlatego, że próbuje się w ten sposób wzmocnić i z góry zagwarantować pewność osobistego i społecznego zbawienia. Zapewnia to sukces w rozwoju przedsiębiorstw, jak i możliwość wyprodukowania zbawienia materialnego dla innych. Owa autocertyfikacja świadomości zbawienia jest o tyle niepoprawna, że całkowicie pomija najwyższe dobro partnerów społecznych, tj. wytworzenie sprawiedliwości dostępnej dla każdego i bazującej na zharmonizowanej dystrybucji praw, obowiązków i dóbr, oraz ich zbawczą i społeczną autocertyfikację.

Europejska riposta Habermasa na neoliberalną globalizację próbuje wyleczyć człowieka z perwersji charakterystycznej dla takiej liberalnej świadomości moralnej. Chce zwrócić republikańskiej władzy politycznej jej siłę orientacji, odbudowując moralną autentyczność demokratycznych racji w celu wykluczenia owej perwersji zawczasu i powstrzymania jej przed zawładnięciem dynamiką totalnego eksperymentowania na komunikacji społecznej. Wobec powszechnej nieufności, którą wzbudzają przepisy polityczne, trzeba by było przywrócić zasadność starym i nowym normom, w których może odnaleźć się człowiek współczesny - ponownie uzasadniając swoją przynależność do tychże, tym razem racjonalnie. Jeśli będziemy dobrze uważać, aby otoczyć debatę publiczną gwarancjami pozwalającymi zapewnić każdemu całkowitą wolność wobec zewnętrznych ograniczeń, które ciążą zazwyczaj na komunikacji, za regułę sterującą tą debatą możemy uznać prawo ulegania wyłącznie najlepszym argumentom. Jedynie owa siła najlepszego argumentu mogłaby usytuować ową debatę tak, jak należy: ponad mieszanką interesów prywatnych czy zbiorowych oraz kapitalistycznych stosunków sił (rapports de force). Jedynie ona byłaby godna 
stanowienia prawa, przywracając stosunek słusznej proporcjonalności pomiędzy prawami, obowiązkami oraz szczęściem społecznym i indywidualnym, które mogłyby być przypisane czy dostępne dla każdego.

Albowiem uległość wobec najlepszego argumentu w poszukiwaniu powszechnych potrzeb oraz norm, które można uczynić powszechnymi, musi zaświadczać w dyskusji, że rzeczywiście chodzi o potrzeby i normy odczuwane przez wszystkich jako obiektywne i wspólne, jako kluczowe dla ludzi i niezależne od pragnień żywionych tylko przez niektórych, dążących wszelako do tego, by zostały one uznane jako takie przez innych. Egalitarne przydzielanie każdemu autarkicznej wolności do pełnienia zarówno ról społecznych, jak i wszystkich ról argumentacyjnych w tej dyskusji publicznej, zakłada gwarancję osiągnięcia, w miarę możliwości, wyników docelowych: możliwości rozpoznania potrzeb i norm, które czynią każdego niezależnym. Wystarczyłoby przyznać, że ta dynamika argumentacyjna może być wprowadzona lub jest już obecna $\mathrm{w}$ rozmaitych przestrzeniach publicznych, które ożywiają polityczną przestrzeń publiczną za pomocą tych instytucji, jakie konstytucja danego kraju uprawnia do tworzenia opinii publicznej, czyli parlamentów, sądów i administracji (Habermas, 1987a; Habermas, 1987b; Habermas, 1997a; Habermas, 1997b; Habermas \& Rawls, 1997) ${ }^{1}$. Zdalibyśmy sobie wówczas sprawę, że żyjemy już w takiej demokracji deliberatywnej, która urzeczywistnia jedynie to, o czym te przestrzenie komunikacyjne otaczające i przewodzące sprawowaniu władzy się wypowiedziały.

Czy ta terapia legislacyjna wzajemnej alienacji i niesprawiedliwości społecznej może osiągnąć swoje cele w demokracjach, które pozostają zewsząd zdominowane przez hegemonię rynku? Z trudnością. Argumentacyjne naśladowanie kryzysu orientacji społecznej czy też komunikacji, jakie zachodzi w parlamentach, sądach i administracjach, nawet jeśli podnosi ono liberalną negację, którą teoretycy liberalnej sprawiedliwości przeciwstawiają uznaniu kapitalistycznej pauperyzacji i alienacji społecznej, w istocie jedynie przenosi polityzację życia społecznego w przestrzeń dyskusyjną, gdzie już rozwija się myśl nad wzajemnym usprawiedliwianiem się jednostek względem reszty — tam, gdzie uważają one, że albo są w stanie lub nie odpowiadać na wspólne oczekiwania, albo rozstrzygać, które normy odpowiadają tym oczekiwaniom, a które nie.

${ }^{1}$ Polskie tłumaczenia francuskich przekładów, do których odwołuje się Poulain, to odpowiednio: Habermas, 1999; Habermas, 2002; Habermas, 2005a; Habermas, 2005b. Pozycja Habermas \& Rawls, 1997 jest zbiorem artykułów obu autorów, w których polemizowali oni ze sobą. Polski przekład tekstu Habermasa można znaleźć w pracy: Habermas, 2009: 59-84. Odpowiedź Rawlsa - opublikowana pierwotnie, tak jak tekst Hebermasa, jako osobny artykuł (Habermas, 1995; Rawls, 1995), dołączona została później do wydanej już po śmierci Rawlsa reedycji jego Political liberalism (Rawls, 2005: 372-434). Polskie thumaczenie tej ostatniej pracy (Rawls, 1998) bazuje na wydaniu wcześniejszym, stąd też wyżej wspomnianej odpowiedzi nie zawiera (przyp. red. - W.H.). 
W takiej postaci, w jakiej zostaje osiągnięty dzięki niepozostającej w niczyjej dyspozycji sile najlepszego argumentu, nowy konsensus regulacyjny jest zawsze doświadczany jako przestrzeń kolektywnej gratyfikacji retorycznej, w którą magicznym sposobem przenosi się przekonanie powiązane z tym najlepszym argumentem, tak że z jednej strony nie można wyodrębnić obiektywności kolektywnego osądu, a z drugiej ograniczeń instytucjonalnych czy rynkowych, które pozostają w tle tej dyskusji. Argumentacyjna autarkia, której wówczas doświadczamy, nie byłaby więc w stanie w magiczny sposób wytworzyć jakiejśs obiektywnej pewności, takiej jak ta dotycząca obiektywności autonomii, którą tak żarliwie chcemy osiągnąć.

\section{GRANICE WSPÓŁCZESNEJ DEMOKRACJI A POSŁUGIWANIE SIĘ UMIEJĘTNOŚCIĄ SĄDZENIA}

Owo zglobalizowane przybranie na sile kolektywnej ślepoty i niesprawiedliwości społecznej jest jednak jedynie objawem choroby refleksji i wywodzi się z pewnego filozoficznego błędu, dotyczącego „natury” człowieka. Obraz człowieka, jaki tworzy liberalizm, jest rzeczywiście błędny. Od czasów Platona antagonistyczne stosunki pożądań, mające odzwierciedlać odwieczny antagonizm bogów, zostały hojnie przyznane ludziom jako ich determinująca „natura”, wywodząca się z wszczepienia duszy w ciało, a później jako liberalny politeizm wartości, co zauważył Weber. Ta agonistyczna natura jest rzutowana przez nowoczesność na intersubiektywne i polityczne stosunki międzyludzkie, aż do uczynienia z człowieka — jako pożądania przeciwstawionego duchowi — wroga siebie samego i przekształcenia go, wedle sławnego powiedzenia Thomasa Hobbesa, w wilka wobec drugiego człowieka, a następnie przekształcenia polityki $\mathrm{w}$ liberalizmie w politykę grup o antagonistycznych interesach.

Mamy tutaj do czynienia z pewnym filozoficznym błędem, wywodzącym się z niewiedzy, w której tkwiliśmy zarówno w starożytności, jak i w nowożytności, dotyczącym sposobu, w jaki rodzi się w człowieku stosunek do pożądań jako stosunek a priori racjonalny, wywodzący się z identyfikacji ludzi z językiem. Toteż po prostu błędem jest próba uchronienia się przed nim za pomocą niedającego się zatrzymać politycznego systemu obrony - konieczne jest poddać ów stosunek osądowi co do prawdziwości. Błędowi temu towarzyszyło pewne przekonanie, które również okazało się niewłaściwe: wierzenie historyczne, a także współczesne, że człowiek jest w stanie zmienić się bezpośrednio, zgodnie z wymogami świadomości etycznej. Dziś błąd ten jest związany z nowoczesnym wierzeniem, że człowiek może zmienić się jedynie zgodnie z wymogami etycznymi eksperymentowania komunikacyjnego i dyskusji argumentacyjnej. W tych wszystkich przypadkach staramy się wcielić sprawiedliwość politycznego liberalizmu lub racji argumentacyjnej w system 
wiedzy, praw i norm prawnych czy jeszcze w parlamentarny, sądowniczy i administracyjny system komunikacyjny. System ten musi w obu przypadkach funkcjonować jako sztywny odpowiednik instynktu, łączącego poprzez korelacje bijektywne bodźce, reakcje i działania konsumacyjne, to znaczy, musi on funkcjonować jako system samodzielnie przekształcający „,wierzę źle uformowane” (Louis Bolk) i ,jeszcze nieustalone” (Friedrich Nietzsche), jakim jest człowiek, w istotę dobrze uformowaną: w sztywny i niezawodny system koordynacji, w jeden i jedyny system działań i pożądań, w jeden i jedyny system percepcji kognitywnych i stymulacyjnych.

Owa koncepcja zoon logicon, spadek po Arystotelesie, przejęta przez utylitarystów, liberałów i moralistów, pozostaje obecna w koncepcji pierwotnych interesów i dóbr, charakterystycznej zarówno dla liberalnej teorii sprawiedliwości, jak i dla demokracji deliberatywnej. Wszelako ta koncepcja antropologiczna jest błędna z tego względu, iż z początku istnieją u człowieka jedynie wewnątrzgatunkowe instynkty żywieniowe, seksualne i obronne. $\mathrm{Na}$ próżno więc staramy się ustanowić na ich podstawie koordynacje instytucjonalne wobec środowiska fizycznego i społecznego, które byłyby jednakowo sztywne i niezawodne jak instynkty dobrze uformowanych zwierząt. A zatem kiedy szukamy politycznego rozwiązania problemu zaistniałego wskutek totalnego eksperymentowania ożywiającego liberalizm, uciekamy się do mocy języka, używanego w celu ochrony człowieka przed agresją ze strony innych, tegoż języka, który dał się poznać w swojej użyteczności publicznej w religiach, w których występowało bóstwo panujące, języka jako instytucji princeps $\mathrm{w} \dot{z} y c i u$ politycznym. To właśnie w jego politycznym zastosowaniu szukamy odpowiednika dla instynktu regulacji oraz arbitralnie ograniczamy jego użycie do sfery prawnej, moralnej i politycznej.

Analiza porażki nieodłącznie wiążącej się z globalizacją nauczyła nas jednak, że człowiek nie jest mieszanką ducha i ciała, jaką zrobiła z niego filozofia, dając mu za zadanie zapewnienie, poprzez tworzenie swojej historii, panowania ducha nad ciałem i pożądaniami. Wbrew temu wszystkiemu jest on przede wszystkim zarówno jako ciało, jak i jako istota obdarzona afektami i duchem, bytem komunikacji z samym sobą oraz z innymi, tj. bytem, który może umocować się w swoich działaniach i pożądaniach, jedynie przyznając, że jest równie obiektywnie swoimi działaniami i pożądaniami, jak twierdzi, że nimi jest, i może sprawić, by druga osoba to przyznała. Może więc umocować się w nich jedynie poprzez dzielenie się sądem co do obiektywności tychże, tak jak robi to w stosunku do swojej wiedzy: owe działania i pożądania nie mogą więc być obiektem jakiejś arbitralnej woli, ale koniecznie wchodzą w całość niezbędnych stosunków, które łączą człowieka ze światem i zjawiska tego świata między sobą.

Jako byt komunikacyjny, przyznaje on więc z konieczności, że nie jest w stanie zdobyć raz na zawsze kodeksu prawa, kodeksu moralnego czy politycznego 
działania oraz wyników tychże, jak i sądu o prawdzie i dzielenia się nią, albowiem nie może on arbitralnie podporządkować pojawienia się tego porozumienia odnośnie do obiektywności i prawdy zwykłej chęci, indywidualnej czy kolektywnej, stworzenia tegoż. W ten sposób liberalne i konsensualne eksperymentowanie człowieka na drugim człowieku ukazuje filozoficznej krytyce europejskiej, że istota ludzka nie może dosięgnąć celów (fins), jakie postawiła historii, nie może nadać sobie raz na zawsze formy. Powiązane z krytyką wydawanie osądu co do prawdziwości odnośnie do własnych działań i pożądań, w momencie kiedy człowiek powołuje prawdę tak obiektywną, jak twierdzi, że jest, stanowi jedyną instancję regulującą działanie, jaka mu jest dana.

Prawo do wydawania osądu co do prawdziwości jest rdzeniem wszelkich praw, albowiem praktykowanie umiejętności sądzenia opiera się jedynie na umiejętności każdej jednostki do obiektywizowania obiektywnych warunków, jak również na prawdach, do których pozwala ono dotrzeć, oraz na dzieleniu się nimi: umiejętność wydawania osądu sprawia, że każdy z nas dostępuje swojego człowieczeństwa wyłącznie dzięki sprawianiu, że jego prawda zostaje uznana przez drugiego człowieka $\mathrm{w}$ taki sam sposób, w jaki on ją uznał. Publiczne uznanie tegoż prawa do sądzenia idzie zatem $\mathrm{w}$ parze $\mathrm{z}$ uznaniem demokracji jako obiektywnego warunku życia ludzkiego. Aby więc prawo to nie pozostało jedynie pustym słowem, nie możemy zadowolić się taką jego ochroną, jakby chodziło o posiadłość, do której przyznajemy komuś prawo wstępu dzięki czysto defensywnej, umownej i negatywnej koncepcji praw. Należy mianowicie promować rozwój umiejętności formułowania sądu, przyznając każdemu obywatelowi to, co pozwala mu na bycie pełnoprawnym obywatelem świata: zapewniając mu warunki uniwersalizacji wynikające z filozoficznej kultury sądzenia.

\section{DIALOG TRANSKULTUROWY I AKADEMICKI JAKO WARUNEK DEMOKRACJI KOSMOPOLITYCZNEJ}

Prawo i obowiązek sądzenia, nadawane każdemu człowiekowi poprzez wypełnianie roli wypowiadającego się oraz słuchacza samego siebie i drugiej osoby, wywodzi się z jego statusu bytu językowego. Prawo to może być poszanowane jedynie, kiedy respektuje ono rezultaty wydawania sądu i zarazem sprawia, że są one respektowane: kiedy za jego przyczyną inni uznają, iż wyrażone w sądzie prawdy są zarówno prawdami życiowymi, jak i prawdami wypowiedzianymi. Albowiem istota ludzka odróżnia się od innych istot żywych, od zwierząt, tym, że nie jest więźniem natury biologicznej, która w sztywny sposób zaprogramowałaby jego postrzeganie, działanie i szczęście i która byłaby możliwa do wyrażenia w postaci listy właściwości: jako byt wybrakowany, pozbawiony dziedzicznych koordynacji wewnątrzgatunkowych, zwanych instynktami, musi on wymyślić swoje percepcje, działania, myśli i pożądania oraz rozpoznać w nich 
swoje warunki życia, dzieląc się nimi za pomocą tego, co nazywamy kulturą. Ta pozytywna wolność może zostać uznana jedynie wtedy, kiedy pozwoli się każdemu doświadczyć warunków życia, które on uznaje za swoje za pomocą wydawania osądu, i uzyskać tym samym poszanowanie ich różnorodności, wpisanej w pluralizm kultur: pozwalającej mu otworzyć się na tolerancję oraz dialog inter- i transkulturowy.

W kontekście wojny kultur dialog inter- i transkulturowy wydaje się konieczny jako sprawdzenie zdolności każdej kultury do zaprezentowania się jako formy życia dopuszczalnej przez tych wszystkich, którzy w niej uczestniczą, jak i przez innych. Każda kultura potrzebuje krytycznego dialogu między kulturami jako jednego ze swych nieodzownych elementów. Dyskurs krytyczny nie jest bowiem byle jaką okazją dla danej kultury do samoutwierdzenia się: jest on instancją, za pomocą której uświadamia ona sobie swoje ograniczenia w samym zrozumieniu innych kultur, jak również potrzebę wyjścia dialogu interkulturowego od czystego stosunku komunikacji i rejestracji wzajemnego zrozumienia czy wzajemnego niezrozumienia. Dzięki temu nadarza się możliwość dostrzeżenia, w jaki sposób niezbędne stosunki komplementarności kulturowej odkrywają pewne stałe antropologiczne, które mogą być uznane jedynie, kiedy zostaną przyjęte przez partnerów kultur uczestniczących. To właśnie w tym dyskursie krytycznym granice właściwe różnym kulturom mogą zostać dostrzeżone, a sposób, w jaki partnerzy kulturowi te granice przekraczają, może zostać wcielony do kultury wyjściowej. Szacunek kultur wobec innych w dialogu kulturowym rzeczywiście nie może ograniczać się do formalnej postawy, gdzie uznaje się istnienie innej kultury w ten sam sposób, w jaki prawo zobowiązuje nas do respektowania istnienia innej osoby. Musi to być szacunek wyrażany w samym akcie krytyki, poprzez który dana kultura uznaje powinność przyswojenia tego, czego jej brakuje, a co stanowi podstawę innej kultury, z którą ta pierwsza prowadzi dialog. Owo uznanie specyficzności innych kultur w działaniu ich prawdy antropologicznej oraz ich realnego wkładu w konstruowanie człowieczeństwa (construction de l'bumanité) na tyle odpowiadającego temu, czym powinno się stać, czym powinno naprawdę być, warunkuje siłę krytyczną dialogu interkulturowego. Pozwala on więc na krytyczne angażowanie się każdej jednostki w przekształcanie swojej kultury i instytucji, jakie się z niej wywodzą, tak samo jak na pojawienie się w innych kulturach, dzięki uznaniu, które mogą przyznać jego wkładowi partnerzy w dialogu uformowani w danej kulturze, wiary, że wkład krytyczny kultury obcej został rozpoznany w swojej prawdziwości antropologicznej.

Prawda ta powoduje tym samym uznanie, że wszelka komunikacja jest w tym sensie komunikacją publiczną oraz że jest nią już — jako przestrzeń publiczna ukonstytuowana i zinstytucjonalizowana jako taka - tylko dlatego, że jest wymianą krytyczną akademickiego osądu, który polega jedynie na samym sobie i na swojej zdolności do przedstawiania takiego świata, w jakim 
jest on prawdziwy. Komunikacja z tego tylko powodu jest zdolnością powoływania do istnienia świata za pomocą myśli, że wyrażony sąd może pokazać, iż ów świat jest już obecny jako rzeczywistość, jako świat ludzki. Sąd może pokazać, że prawdą jest, iż świat ten jest tak samo rzeczywisty, jak przedstawia go sąd, w postaci, jaką mu nadał. Uniwersytet, uznając się za już istniejącą formę wszelkiej komunikacji, koniecznie uniwersalizuje się zatem w tej perspektywie eksperymentowania na człowieku dzięki komunikacji, ta bowiem nie może ślepo zaspokoić pragnienia konsensusu. Może go jednak osiągnąć poprzez utożsamienie człowieka z bytem będącym sędzią prawdy, z bytem teoretycznym, poprzez podlegający osądowi proces eksperymentowania człowieka na sobie samym. Uniwersytet wykonuje więc już swoje zadanie początkowej, środkowej i końcowej fazy bezpośredniej transformacji człowieka dokonującej się na nim samym. Jest nią owo pełne eksperymentowanie na człowieku, albowiem dokonuje się ono koniecznie poprzez osąd co do prawdziwości, naniesiony na formy życia, na których został przeprowadzony eksperyment, oraz poprzez dzielenie się nim. Owo odnoszenie się do sądu i dzielenie się nim są akademickie zarówno w swojej formie, jak i w treści. Uniwersytet okazuje się więc czymś znacznie więcej niż zwykłą instytucją: jest on instytucją wiedzy, o której można stwierdzić, że jest już formą życia, i to jedyną formą odpowiadającą człowiekowi, albowiem instytucja ta wyraża i rozwija jedynie dynamikę i logikę inherentną wszelkiej komunikacji: wyraża siłę kreatywną świata, nanosząc swoją krytykę na świat, który tworzy, oraz sprawiając, że krytyka ta jest podzielana przez wszystkich, zarówno w kwestii jej przeprowadzania, jak i w odniesieniu do uzyskanych przez nią wyników. W ten również sposób uniwersytet może ustalić w postaci krytycznego sądu antropologicznego, że człowiek nie może stać się owym bytem perfekcyjnie władającym sobą, którego poszukuje poprzez totalne eksperymentowanie na samym sobie, albowiem, aby tego dokonać, musiałby zrezygnować $\mathrm{z}$ bycia tym, kim jest - z owego dzielenia się sądem na temat siebie samego i świata - aby spełnić marzenie suwerenności.

Uniwersytet jest również $\mathrm{w}$ stanie narzucić posługiwanie się zdolnością sądzenia $\mathrm{w}$ ramach eksperymentowania, które odmawia posługiwania się nią i zastępuje ją ślepym konsensusem. Jest w stanie to zrobić jedynie poprzez przywrócenie przestrzeni wspólnej afirmacji, uznającej u swych podstaw, że wytworzone publiczne światy - przemysłowe, ekonomiczne, sądownicze, moralne czy polityczne - są właśnie takimi obiektywnymi warunkami życia, jakimi powinny być, i istnieć tak, jak istnieją, lub przeciwnie, że nie są takimi i dlaczego. To właśnie tak, na swój sposób, uniwersytet bierze pod uwagę, że człowiek nie może sam bezpośrednio się przekształcić ani uzyskać konsensualnej władzy nad sobą i innym człowiekiem, nie mając pewności co do obiektywności tego świata i form życia, które w nim rozwija, tj. bez przejścia przez dzielenie się osądem co do prawdziwości, które może sprawić, iż uzna się, że rzeczywiście jest on tak samo prawdziwy, jak prawdą jest, że takim się deklaruje. 
Uniwersytet musi więc przyznać, że jest uniwersalną i krytyczną formą życia wewnątrz życia akademickiego, musi więc rozwijać i spełniać się jako taki, ale musi również przyznać, że wszelka przestrzeń publiczna jest lub musi być akademicka w tym sensie, iż istnieje ona już jako działająca i niezależna tylko dzięki owej praktyce sądzenia. Uniwersytet może tego dokonać, jedynie dowodząc, że przemiany przestrzeni komunikacji ekonomicznej, przemysłowej, politycznej czy etycznej, które go zdominowały, aby przezwyciężć zglobalizowane niepowodzenie jego woli władzy, dokonały się z sukcesem tylko dlatego, że jednostki, przedsiębiorstwa, instytucje, grupy i państwa zgodzity się dokonać na sobie samych przemiany z bytu woli władzy w byt sądu, byt teoretyczny.

Jeśli weźmie się pod uwagę na przykład niedawny rozłam międzykulturowy pomiędzy liberalizmem, republikanizmem europejskim i kulturą muzułmańską, to trzeba, po pierwsze, uznać konieczność rozprzestrzeniania kontraktowej kultury liberalizmu amerykańskiego, rozpoznając stosunki konieczności łączące rozwój kultur społecznych ze światem i z ludzką rzeczywistością, rozpoznając stosunki konieczności, które obligują do uznania obiektywności praw rządzących transakcjami ekonomicznymi oraz narzucających warunki sprawiedliwej rekompensaty dóbr, praw i obowiązków. Jedynie to przyznanie może pozwolić europejskiemu marzeniu o światowej demokracji deliberatywnej uciec swoim wewnętrznym ograniczeniom etycznym. Kultura muzułmańska przedstawia możliwość krytyki wewnętrznych ograniczeń myśli.

Jednak krytyka uniwersytecka musi, po drugie, stać się również krytyką transkulturową $\mathrm{w}$ tym sensie, że powinna przyjąć punkt widzenia innych kultur - aby móc te punkty widzenia zrozumieć i sprawdzić ich kulturową kreatywność, jak i ich zdolność krytyczną, należy myśleć nie tylko, że drugi człowiek może mieć rację, ale też że ją ma, biorąc jednocześnie to, co myśli, za prawdę, by następnie uznać lub nie, iż prawdą jest, że może być to nieprawdą.

Owa niedostępność jedynego kryterium dla antropologicznego krytycznego dialogu międzykulturowego - zgoda co do prawdy u drugiego człowieka była być może tym, co chciano osiągnąć poprzez zakaz przywłaszczania sobie mocy sądzenia ostatniej instancji, która to przypadała Bogu żydowskiemu. Należy więc wysłuchać przesłania prawdy kultury żydowskiej: jest nią ukazanie niezdolności istoty ludzkiej do uznania za prawdziwe tego, o czym mówi i myśli, póki nie sprawi ona, że druga osoba podzieli jej sąd co do prawdziwości, powodując, iż ta uzna obiektywność doświadczenia samego siebie oraz świata, co wówczas czyni. Być może stanowi to ukrytą żydowskość i islamskość tego, co europejskie. Być może stanowi to wewnętrzne ograniczenie użycia sądu filozoficznego - codziennego czy uniwersyteckiego - o ile prawdą jest, że owo dzielenie się nim i dawanie drugiemu człowiekowi, jak i sobie samemu warunków dostępu do niego, stanowi jedyne świadectwo istnienia tej prawdy, która aby być, musi być wspólna i rozpoznana przez wszystkich tych, 
których wypowiadający się może uznać za towarzyszy w eksperymencie dialogu transkulturowego.

\author{
Przełożyta Kornela OLEJARZ*
}

\title{
Przekład przejrzat i naukowo opracowat Wojciech HANUSZKIEWICZ**
}

\section{BIBLIOGRAFIA}

Habermas, J. (1987a). Théorie de l'agir communicationnel (t. 1 : Rationalité de l'agir et rationalisation de la société). (Przeł. J.-M. Ferry). Paris: Fayard.

Habermas, J. (1987b). Théorie de l'agir communicationnel. (t. 2 : Pour une critique de la raison fonctionnaliste). (Przeł. J.-L. Schlegel). Paris: Fayard.

Habermas, J. (1995). Reconciliation through the public use of reason: Remarks on John Rawls's political liberalism. Journal of Philosophy, 92(3), 109-131.

Habermas, J. (1997a). Droit et démocratie. Entre faits et normes. (Przeł. Ch. Bouchindhomme \& R. Rochlitz). Paris: Gallimard.

Habermas, J. (1997b). Droit et morale. „Tanner Lectures” (1986). (Przeł. Ch. Bonchindhomme \& R. Rochlitz). Paris: Seuil.

Habermas, J. (1999). Teoria działania komunikacyjnego (t. 1: Racjonalność działania a racjonalność społeczna). (Przeł. A.M. Kaniowski). Warszawa: Wydawnictwo Naukowe PWN.

Habermas, J. (2002). Teoria dziatania komunikacyjnego (t. 2: Przyczynek do krytyki rozumu funkcjonalnego). (Przeł. A.M. Kaniowski). Warszawa: Wydawnictwo Naukowe PWN.

Habermas, J. (2005a). Faktyczność i obowiazywanie: teoria dyskursu wobec zagadnień prawa i demokratycznego państwa prawnego. (Przeł. A. Romaniuk \& R. Marszałek). Warszawa: Wydawnictwo Naukowe Scholar.

Habermas, J. (2005b). Prawo i moralność (s. 470-520). W: J. Habermas. Faktyczność i obowiqzywanie: teoria dyskursu wobec zagadnień prawa i demokratycznego państwa prawnego. (Przeł. A. Romaniuk \& R. Marszałek). Warszawa: Wydawnictwo Naukowe „Scholar”.

Habermas, J. (2009). Uwzględniając Innego: studia do teorii politycznej. (Przeł. A. Romaniuk; przekł. przejrzał J. Kloc-Konkołowicz). Warszawa: Wydawnictwo Naukowe PWN.

Habermas, J. \& Rawls, J. (1997). Débat sur la justice politique. (Przeł. R. Rochlitz; współpr. C. Audard). Paris: Cerf.

Rawls, J. (1995). Political liberalism: Reply to Habermas. The Journal of Philosophy, 92(3), 132-180.

Rawls, J. (1998). Liberalizm polityczny. (Przeł. A. Romaniuk; wstęp Cz. Porębski). Warszawa: Wydawnictwo Naukowe PWN.

Rawls, J. (2005) [1993]. Political liberalism. New York: Columbia University Press.

* Mgr filologii francuskiej, absolwentka Uniwersytetu Jagiellońskiego. E-mail: kornelaolejarz@gmail.com.

** Dr, adiunkt, Instytut Filozofii i Socjologii, Uniwersytet Pedagogiczny im. KEN w Krakowie. E-mail: wojciech.hanuszkiewicz@up.krakow.pl. 